\title{
Vegetation analysis of non-tidal swampland in South Sumatra, Indonesia and its carrying capacity for Pampangan buffalo pasture
}

\author{
MUHAKKA ${ }^{1,2, \boldsymbol{v}}$, RUJITO AGUS SUWIGNYO ${ }^{3}$, DEDIK BUDIANTA ${ }^{4}$, YAKUP $^{3}$ \\ ${ }^{1}$ Graduate School, Universitas Sriwijaya. Jl. Padang Selasa No. 524, Palembang 30139, South Sumatra, Indonesia. Tel./fax.: +62-711-581106. \\ •email: muhakka@fp.unsri.ac.id \\ ${ }^{2}$ Department of Animal Husbandry, Faculty of Agriculture, Universitas Sriwijaya. Jl. Palembang-Prabumulih Km. 32, Inderalaya, Ogan Ilir 30662 , \\ South Sumatra, Indonesia \\ ${ }^{3}$ Department of Agronomy, Faculty of Agriculture, Universitas Sriwijaya. Jl. Palembang-Prabumulih Km. 32 Inderalaya, Ogan Ilir 30662, \\ South Sumatra, Indonesia \\ ${ }^{4}$ Department of Soil Science, Faculty of Agriculture, Universitas Sriwijaya. Jl. Palembang-Prabumulih Km. 32 Inderalaya, Ogan Ilir 30662 , \\ South Sumatra, Indonesia
}

Manuscript received: 4 January 2018. Revision accepted: 23 March 2019.

\begin{abstract}
Muhakka, Suwignyo RA, Budianta D, Yakup. 2019. Vegetation analysis of non-tidal swampland in South Sumatra, Indonesia and its carrying capacity for Pampangan buffalo pasture. Biodiversitas 20: 1077-1086. In Indonesia, non-tidal swampland area is 13.27 million ha, only 4 million ha has been developed with details of 2.6 million ha that managed by the public and the private sector and 1.3 million ha with government assistance. This study aims to analyze vegetation structure of non-tidal swampland in Pulau Layang Village, Ogan Komering Ilir District, South Sumatra, Indonesia and Rambutan Village, Banyuasin District, South Sumatra, Indonesia and to examine its carrying capacity for Pampangan buffalo pasture. Methods used were by the combination of direct observation, survey using plot sampling with total 50 observation plots, and measurements to determine forage production using Halls method. The results show that there 19 forage species were in two studied areas which are potential as Pampangan buffalo feed. Species with the highest Important Value Index were Purun tikus (Eleocharis .dulcis) with $89.71 \%$ and Kumpai padi (Oryza. rufipogon) with $54.08 \%$. The production of fresh forage and dry matter in the wet season in Pulau Layang was 6.90 tons $^{-1} \mathrm{hear}^{-1}$ and 1.27 tons ha $^{-1}$ year ${ }^{-1}$, respectively, whereas in Rambutan they were 3.68 tons ha $^{-1} \mathrm{year}^{-1}$ and 0.91 tons $\mathrm{ha}^{-1}$ year ${ }^{-1}$, respectively. The production of fresh forage and dry matter in the dry season in Pulau Layang was 4.86 tons ha $^{-1}$ year ${ }^{-1}$ and 0.99 tons $\mathrm{ha}^{-1}$ year $^{-1}$, respectively, while in Rambutan they were 2.52 tons ha ${ }^{-1}$ year $^{-1}$ and 0,71 tons ha $^{-1}$ year-1 $^{-1}$, respectively. The pasture carrying capacity in Pulau Layang in the wet season was 3.66 AU (Animal

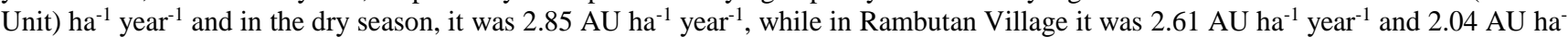
${ }^{1}$ year $^{-1}$, respectively. There were six species of forage with high production, namely Kumpai tembaga (Hymenachne acutigluma) Kumpai padi (Oryza rupifogon), Kumpai minyak (Hymenachne amplexicaulis), Are bolong (Polygonum barbatum L), Bento rayap (Leersia hexandra) and Purun tikus (Eleocharis dulcis). It is estimated that there still can be added buffalo cattle as much as 0.31 AU ha ${ }^{-1}$ year $^{-1}$ in Pulau Layang Village so 155 buffaloes and $0.59 \mathrm{AU} \mathrm{ha}^{-1}$ year $^{-1}$ in Rambutan Village. 709 buffaloes
\end{abstract}

Keywords: Pampangan buffalo, vegetation analysis, carrying capacity, pasture, non-tidal swampland

\section{INTRODUCTION}

Non-tidal swampland is often considered as suboptimal land despite its availability is very extensive in Indonesia. The total extent of non-tidal swampland is about 13.27 million ha, consisting of 3.0 million ha of deep swampland, 6.07 million ha of swampland with medium deep and 4.20 million ha of shallow swampland, and is distributed in Sumatra, Kalimantan, and Papua. Nonetheless, there is only 4 million ha of them have been developed with public and private sectors manage 2.60 million ha while 1.3 million ha are developed by government assistance (BPS 2010; Mulyani and Sarwani 2013). At provincial level, non-tidal swampland in South Sumatra covers the most extensive area in Sumatra, reaching 2.98 million ha but only 298,189 ha that has been developed (BPS 2014).

Pampangan buffalo is potential germplasm of South Sumatra Province which is widely found and extensively farmed in Pulau Layang Village, Ogan Komering Ilir District and Rambutan Village, Banyuasin District (Muhakka et al. 2013). In addition to being farmed for their meat, the buffalo also produce milk to be processed into traditional food named Gulo Puan. Buffalo population in South Sumatra in 2014 was 33,369 buffaloes, decreasing 4.29\% than that in 2012 with 34,866 buffaloes (South Sumatra Province Animal Husbandry Office 2014). There are three factors causing the decline in the buffalo livestock population, namely: (i) fluctuated availability of natural forage, (ii) low quality of nutritional forage of lowland swamp, and (iii) decreasing extent of grazing pasture land (BPTP South Sumatra 2011). The low productivity of the buffaloes in term of growth and milk production is caused by the consumed rations could not meet the needs for food substances which characterized by low protein content, high crude fiber, and low digestibility. However, the buffaloes have several advantages and their productivity can be enhanced especially through food and genetic improvement (Talib et al. 2014). The buffaloes have advantages compared to cows in which they can survive particularly when available feed has low quality (Diwyanto and Handiwirawan 2006; Yasin 2013). 
One strategy that can be done to maintain and improve the level of productivity of Pampangan buffalo is by studying their forage in lowland swamp by analyzing the vegetation and carrying capacity of pasture. Studies on vegetation analysis and pasture carrying capacity up to date are only limited to dry land areas, such as in Wulan Gitrang Sub-district, East Flores which show carrying capacity of 0.42 AU.ha $^{-1}$.year ${ }^{-1}$ on coffee plantation and 0.38 AU.ha ${ }^{1}$.year ${ }^{-1}$ on grassland (Kleden et al. 2015). Another study investigating carrying capacity of livestock forage during preproduction of rubber (juvenile plants) is $0.14 \mathrm{AU}$. ha ${ }^{1}$.year ${ }^{-1}$, while during rubber production (mature plants) can only accommodate $0.06 \mathrm{AU}$. ha ${ }^{-1}$.year ${ }^{-1}$ (Pramana et al. 2015).
This study aims to analyze vegetation structure of nontidal swampland in South Sumatra and examine its carrying capacity for Pampangan buffalo pasture.

\section{MATERIALS AND METHODS}

This research was carried out in Pulau Layang Village, Pampangan Sub-district, Ogan Komering Ilir District, South Sumatra and Rambutan Village, Rambutan Sub-district, Banyuasin District, South Sumatra from April to September 2017. The methods used were the combination of survey, measurements, and direct observations on samples of swampland commonly used as pasture by farmers. Data of livestock population were collected from related agencies and institutions.

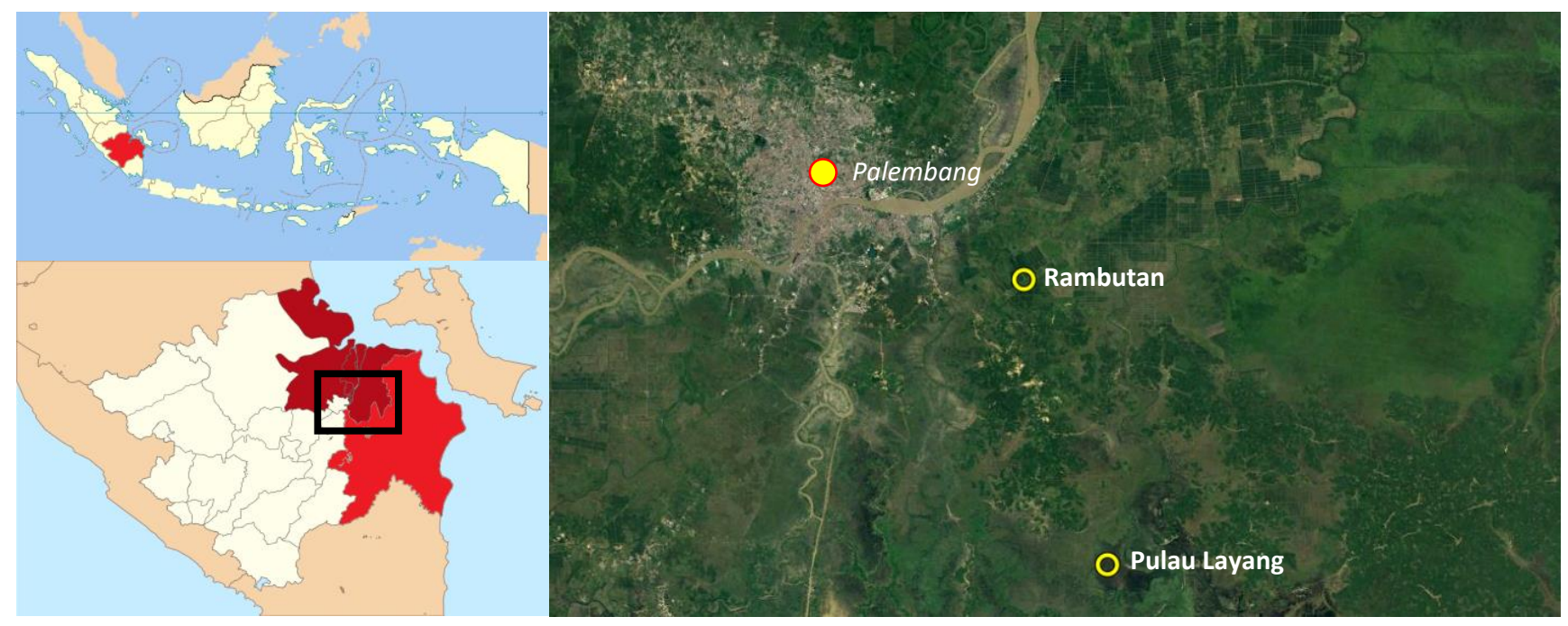

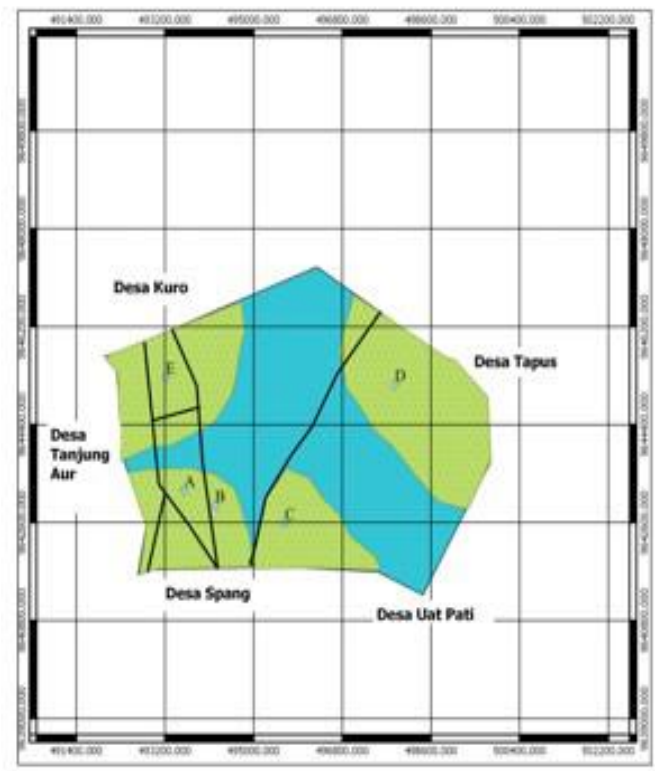

A

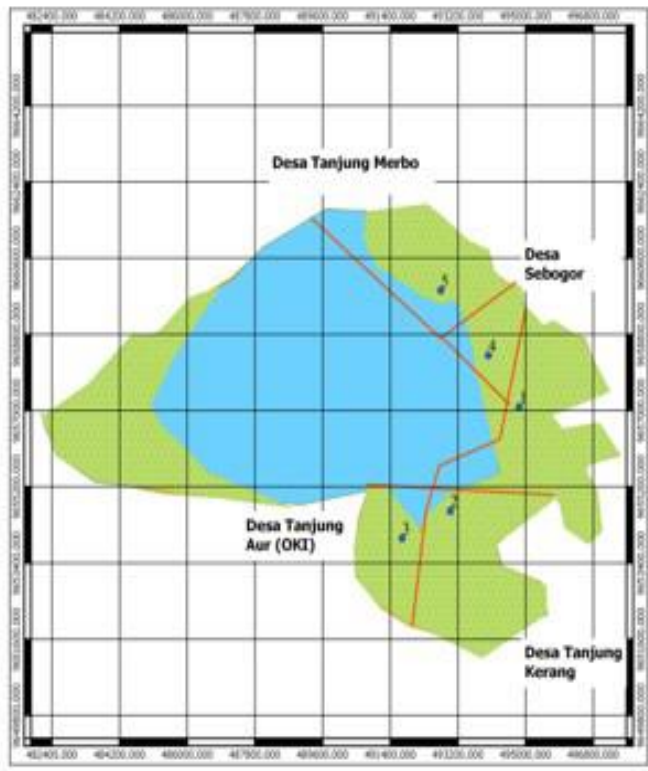

B

Figure 1. Research location in South Sumatra, Indonesia. A. Pulau Layang Village, Pampangan Sub-district, Ogan Komering Ilir District, South Sumatra. B. Rambutan Village, Rambutan Sub-district, Banyuasin District, South Sumatra 
Field data were collected using direct observations and measurements including forage vegetation species, amount of production, forage quality (natural grasses and legumes), and soil fertility. Purposive sampling was conducted by making quadratic plots with size of $1 \times 1 \mathrm{~m}$ each plot and with total number of plots was 50 (Kleden et al. 2015). In each observation plot, the name and individual number of forage species were recorded. The plant specimens were collected and labeled with each species was photographed with digital camera. The collected specimens from each plot were separated according to each species and dried to calculate the dominant value. Dominant value is a value that more important than other values. . The unknown species was collected for herbaria, being treated with $70 \%$ alcohol, oven-dried, and identified the plant is identified by employing a botanist and using reference book.

\section{Vegetation analysis}

The collected data were analyzed quantitatively (Utami et al. 2007) as follows:

\section{Density}

Density is the number of individual of a species per area extent and formulated as follows:

$$
\text { Density }=\frac{\text { Number of individual of a species }}{\text { Total extent of sample plots }}
$$

\section{Relative density}

Relative density is the density of a species as a percent of total plant density and formulated as follows:

$$
\text { Relative density }=\frac{\text { Density of a species }}{\text { Density of all species }}
$$

\section{Frequency}

Frequency is the number of sample plots having a species in a given total number of sample plots and formulated as follows:

Frequency $=\frac{\text { Number of plots having a species }}{\text { Number of all observed plots }}$

\section{Relative frequency}

Relative Frequency is the frequency of a species as a percent of total frequency of all species and formulated as follows:

$$
\text { Relative frequency }=\frac{\text { Frequency of a species }}{\text { Frequency of all species }}
$$

\section{Important Value Index (IVI)}

This value indicates the dominance of a species in a particular area and formulated as follows:

IVI $=$ Relative Density + Relative Frequency

\section{Forage production}

Measurement on forage production adopted the Halls method (Kleden et al. 2015) using a $1 \mathrm{~m}$ x $1 \mathrm{~m}$ quadratic frame (Sutaryo 2009). A total of 50 observation points were done in grazing area of swampland lowland that frequently used by farmers/ranchers. The squared frame for each observation point was randomly placed. The average forage production was calculated using the following formula:

$$
\mathrm{X}=\sum \mathrm{xi} / \mathrm{n}
$$

Where:

$\mathrm{X}$ : The existing average of forage biomass production

$\sum x i$ : The amount of forage biomass production at each observation

$\mathrm{n}$ : The amount of observation

\section{Pasture carrying capacity}

The carrying capacity is the ability of pasture areas or grass farming to accommodate a number of livestock so that the need for grass for one-year-animal feed is sufficient. Calculating forage carrying capacity of swamp lowland forage is based on the amount of forage supplied on pasture for livestock needs for one year which is stated in Animal Unit (AU) per hectare. The carrying capacity was calculated for each species of forage. The calculation adopted formula developed by Purnomo (2006).

\section{Carrying capacity $=\underline{\text { Cumulative production } \mathrm{x} \text { proper use factor }(\%)}$ Animal needs (kg DM/AU/day) x 360 days}

Cumulative Forage Production $=[(\mathrm{hk} / \mathrm{ik} \mathrm{x} \mathrm{pk})+(\mathrm{hp} / \mathrm{ip} \mathrm{x} \mathrm{pp})+(\mathrm{hh} / \mathrm{ih} \mathrm{x} \mathrm{ph})]$

Where:

hk : Number of days in the dry season (90 days)

$\mathrm{hp}$ : Number of days in the transition season (120 days)

hh : Number of days in the wet season (150 days)

ik : Cutting intervals in the dry season (50 days)

ip : Cutting intervals in the transition season (30 days)

ih : Cutting intervals in the wet season (40 days)

pk : Biomass production in the dry season

$\mathrm{pp}$ : Biomass production in the transition season

ph : Biomass production in the wet season

puf: Proper use factor $68 \%$.

$\mathrm{kt}$ : Animal need 6,25 kg dry matter $\mathrm{AU}^{-1}$ day $^{-1}$

\section{Data analysis}

Carrying capacity was analyzed by comparing forage production to the number of livestock available which result in a ratio that informs the number of buffaloes that could be developed in the study area. Three possible ratios are: (i) AUp/AUt < 1 means the number of livestock grazing in swampland is greater than the amount of feed available; (ii) $\mathrm{AUp} / \mathrm{AUt}=1$ means there is a balance between the amount of forage available and the number of livestock; (iii) AUp/AUt > 1 means the number of livestock is less than the amount of food available in the pasture. AU is animal unit equivalents with AUp and AUt are animal units for feed and animal unit for livestock, respectively (Kleden et al. 2015). 


\section{RESULTS AND DISCUSSION}

\section{Forage species}

In the research areas, there were 19 forage species potential to be used as Pampangan buffalo feed, covering 17 grass species (Gramineae) and 2 legume species (Leguminosae) (Table 1).

\section{Analysis of forage vegetation}

The results of vegetation analysis of forage species at Pampangan buffalo pastures in swamp lowland during wet and dry seasons in Pulau Layang Village and Rambutan Village are presented in Tables 2 and 3, respectively.

\section{Forage production}

The average production of fresh forage vegetation of swamp lowland at two study locations was 6.90 tons.ha ${ }^{1}$.year ${ }^{-1}$ in Pulau Layang Village, Pampangan Sub-district, Ogan Komering Ilir District (Table 4) and 3.68 tons.ha- $^{-}$ ${ }^{1}$.year $^{-1}$ in Rambutan Village, Rambutan Sub-district, Banyuasin District (Table 5).

Table 1. Forage species in the studied areas of Pampangan buffalo pasture in non-tidal swampland of South Sumatra, Indonesia

\begin{tabular}{|c|c|c|c|c|}
\hline \multirow{2}{*}{ Latin name } & \multirow{2}{*}{ Local name } & \multicolumn{2}{|c|}{ Village } & \multirow{2}{*}{ Remarks } \\
\hline & & $\mathbf{P}$ & $\mathbf{R}$ & \\
\hline Catharanthus roseus & Tapak dara & + & - & NDP \\
\hline Cyperus cephalotes & Apit-apit & + & - & NDP \\
\hline Cyperus digitatus & Kasuran & - & + & NDP \\
\hline Digitaria fuscescens & Pasiran/Kerak maling & + & + & DP \\
\hline Eichhornia crassipes & Eceng gondok & + & - & NDP \\
\hline Eleocharis dulcis & Purun tikus & + & + & DP \\
\hline Hymenachne acutigluma & Kumpai tembaga & + & + & DP \\
\hline Hymenachne amplexicaulis & Kumpai minyak & + & + & $\mathrm{DP}$ \\
\hline Hymenachne sp. & Kumpai merah & + & - & NDP \\
\hline Ipomoea aquatica & Kangkung merah & + & - & NDP \\
\hline Leersia hexandra & Bento rayap & + & + & DP \\
\hline Ludwigia hyssopifolia & Cecengkehan & + & - & ND \\
\hline Neptunia oleracea & Kemon air & + & - & NDP \\
\hline Nymphaea lotus & Telepuk Gajah & + & - & NDP \\
\hline Nymphaea odorata & Telepuk Padi & + & - & NDP \\
\hline Oryza rufipogon & Kumpai padi & + & + & DP \\
\hline Polygonum barbatum & Are bolong & + & - & DNP \\
\hline Rhynchospora corymbosa & Berondong & - & + & ND \\
\hline Sesbania exasperata & Mutiara & - & + & NDP \\
\hline
\end{tabular}

Note: P: Pulau Layang Village, R: Rambutan Village, DP: Dominant, Palatable, DNP: Dominant, Not Palatable, NDP: Not Dominant, Palatable ND : Not Dominant, Not Palatable means forages that is not liked by buffaloes to eat swampland. +: Present,-: Absent. Dominand means a type of forages that always appears in sampling and have high production.

Table 2. Density, relative density, frequency, relative frequency, and important value index of forage species at Pampangan buffalo pasture during wet and dry seasons in Pulau Layang Village, Pampangan Sub-district, Ogan Komering Ilir District, South Sumatra, Indonesia

\begin{tabular}{|c|c|c|c|c|c|c|c|c|c|c|}
\hline \multirow[b]{2}{*}{ Latin name } & \multicolumn{5}{|c|}{ Wet season } & \multicolumn{5}{|c|}{ Dry season } \\
\hline & $\mathbf{D}$ & $\begin{array}{l}\text { RD } \\
(\%)\end{array}$ & $\mathbf{F}$ & $\begin{array}{l}\text { RF } \\
(\%)\end{array}$ & $\begin{array}{l}\text { IVI } \\
(\%)\end{array}$ & $\mathbf{D}$ & $\begin{array}{l}\text { RD } \\
(\%)\end{array}$ & $\mathbf{F}$ & $\begin{array}{l}\text { RF } \\
(\%)\end{array}$ & $\begin{array}{l}\text { IVI } \\
(\%)\end{array}$ \\
\hline Catharanthus roseus & 0.08 & 2.50 & 0.06 & 3.65 & 6.15 & - & - & - & - & - \\
\hline Cyperus cephalotes & & - & - & - & - & 0.16 & 8.42 & 0.12 & 9.52 & 17.94 \\
\hline Digitaria fuscescens & - & - & - & - & - & 0.16 & 8.42 & 0.12 & 9.52 & 17.94 \\
\hline Eichhornia crassipes & 0.48 & 15.00 & 0.20 & 12.19 & 27.19 & 0.18 & 9.47 & 0.08 & 6.34 & 15.82 \\
\hline Eleocharis dulcis & 0.16 & 5.00 & 0.14 & 8.53 & 13.53 & - & - & - & - & - \\
\hline Hymenachne acutigluma & 0.22 & 6.87 & 0.12 & 7.31 & 14.19 & 0.12 & 6.31 & 0.12 & 9.52 & 15.84 \\
\hline Hymenachne amplexicaulis & 0.20 & 6.25 & 0.10 & 6.09 & 12.34 & 0.14 & 7.36 & 0.08 & 6.34 & 13.71 \\
\hline Hymenachne sp. & 0.46 & 14.37 & 0.18 & 10.97 & 25.35 & 0.20 & 10.52 & 0.12 & 9.52 & 20.05 \\
\hline Ipomoea aquatica & 0.04 & 1.25 & 0.04 & 2.43 & 3.68 & - & - & - & - & - \\
\hline Leersia hexandra & 0.06 & 1.87 & 0.04 & 2.43 & 4.31 & 0.12 & 6.31 & 0.10 & 7.93 & 14.25 \\
\hline Ludwigia hyssopifolia & 0.18 & 5.62 & 0.06 & 3.65 & 9.28 & 0.16 & 8.42 & 0.08 & 6.34 & 14.77 \\
\hline Neptunia oleracea & 0.56 & 17.50 & 0.32 & 19.51 & 37.01 & 0.38 & 20.00 & 0.24 & 19.04 & 39.04 \\
\hline Nymphaea lotus & 0.02 & 0.62 & 0.02 & 1.22 & 1.84 & - & - & - & - & - \\
\hline Nymphaea odorata & 0.02 & 0.62 & 0.02 & 1.22 & 1.84 & - & - & - & - & - \\
\hline Oryza rufipogon & 0.18 & 5.62 & 0.08 & 4.87 & 10.50 & - & - & - & - & - \\
\hline Polygonum barbatum & 0.54 & 16.87 & 0.26 & 15.85 & 32.72 & 0.28 & 14.73 & 0.20 & 15.87 & 30.61 \\
\hline Total & 3.2 & 100 & 1.64 & 100 & 200 & 1.90 & 100 & 1.26 & 100 & 200 \\
\hline
\end{tabular}

Note: D = Density, RD 
Table 3. Density, Relative Density, Frequency, Relative Frequency, and Important Value Index of forage species at Pampangan buffalo pasture during wet and dry seasons in Rambutan Village, Rambutan Sub-district, Banyuasin District, South Sumatra, Indonesia

\begin{tabular}{|c|c|c|c|c|c|c|c|c|c|c|}
\hline \multirow[b]{2}{*}{ Latin name } & \multicolumn{5}{|c|}{ Wet season } & \multicolumn{5}{|c|}{ Dry season } \\
\hline & $\mathbf{D}$ & $\begin{array}{l}\text { RD } \\
(\%)\end{array}$ & $\mathbf{F}$ & $\begin{array}{l}\text { RF } \\
(\%)\end{array}$ & $\begin{array}{l}\text { IVI } \\
(\%)\end{array}$ & $\mathbf{D}$ & $\begin{array}{l}\text { RD } \\
(\%)\end{array}$ & $\mathbf{F}$ & $\begin{array}{l}\text { RF } \\
(\%)\end{array}$ & $\begin{array}{l}\text { IVI } \\
(\%)\end{array}$ \\
\hline Cyperus digitatus & 0.88 & 18.03 & 0.30 & 14.85 & 32.88 & 0.12 & 5.31 & 0.06 & 4.34 & $9.65^{4}$ \\
\hline Digitaria fuscescens & 1.10 & 22.54 & 0.40 & 19.80 & 42.34 & 0.40 & 1.77 & 0.22 & 15.94 & $17.71^{3}$ \\
\hline Eleocharis dulcis & 1.68 & 34.42 & 0.74 & 36.63 & 71.06 & 1.00 & 44.24 & 0.62 & 44.92 & $89.17^{1}$ \\
\hline Hymenachne acutigluma & 0.04 & 0.82 & 0.02 & 0.99 & 1.81 & 0.02 & 0.88 & 0.02 & 1.44 & $2.33^{8}$ \\
\hline Hymenachne amplexicaulis & 0.04 & 0.82 & 0.02 & 0.99 & 1.81 & 0.04 & 1.77 & 0.02 & 1.44 & $3.21^{7}$ \\
\hline Leersia hexandra & 0.06 & 1.23 & 0.04 & 1.98 & 3.21 & 0.04 & 1.77 & 0.04 & 2.89 & $4.65^{5}$ \\
\hline Oryza rufipogon & 0.80 & 16.39 & 0.40 & 19.80 & 36.19 & 0.60 & 26.54 & 0.38 & 27.53 & $54.08^{2}$ \\
\hline Rhynchospora corymbosa & 0.08 & 1.63 & 0.04 & 1.98 & 3.61 & 0.04 & 1.77 & 0.02 & 1.44 & $3.21^{6}$ \\
\hline Sesbania exasperata & 0.20 & 4.09 & 0.06 & 2.97 & 7.06 & - & - & - & - & - \\
\hline Total & 4.88 & 100 & 2.02 & 100 & 200 & 2.26 & 100 & 1.38 & 100 & 200 \\
\hline
\end{tabular}

Note: D = Density, RD = Relative Density, F = Frequency, RF = Relative Frequency, IVI = Important Value Index

Table 4. Fresh weight production (FWP), dry matter production (DMP), and forage carrying capacity (CC) of swamp lowland in wet and dry seasons in Pulau Layang Village, Ogan Komering Ilir.

\begin{tabular}{|c|c|c|c|c|c|c|}
\hline \multirow[b]{2}{*}{ Latin name } & \multicolumn{3}{|c|}{ Wet season } & \multicolumn{3}{|c|}{ Dry season } \\
\hline & $\begin{array}{c}\text { FWP } \\
(\mathbf{k g})\end{array}$ & $\begin{array}{l}\text { DMP } \\
(\mathrm{kg})\end{array}$ & $\begin{array}{c}\text { CC } \\
\left(\text { AU.ha }^{-1} \cdot \text { year }^{-1}\right)\end{array}$ & $\begin{array}{c}\text { FWP } \\
(\mathbf{k g})\end{array}$ & $\begin{array}{c}\text { DMP } \\
\text { (kg) }\end{array}$ & $\begin{array}{c}\text { CC } \\
\left(\text { AU.ha }^{-1} \cdot \text { year }^{-1}\right)\end{array}$ \\
\hline Catharanthus roseus & 7,530 & 977.40 & 2.82 & - & - & - \\
\hline Cyperus cephalotes & - & - & - & 4,580 & $1,145.00^{4}$ & 3.30 \\
\hline Digitaria fuscescens & - & - & - & 2,420 & $537.97^{10}$ & 1.55 \\
\hline Eichhornia crassipes & 5,940 & $1,097.70$ & 3.17 & 4,700 & $830.49^{6}$ & 2.40 \\
\hline Eleocharis dulcis & 12,640 & $2,664.50$ & 7.69 & - & - & - \\
\hline Hymenachne acutigluma & 6,700 & $1,352.70$ & 3.90 & 7,480 & $1,632.54^{1}$ & 4.71 \\
\hline Hymenachne amplexicaulis & 6,650 & 790.00 & 2.28 & 5,990 & $729.58^{8}$ & 2.11 \\
\hline Hymenachne sp. & 7,040 & $1,151.70$ & 3.32 & 5,720 & $975.83^{5}$ & 2.82 \\
\hline Ipomoea aquatica & 4,020 & 604.60 & 1.75 & - & - & - \\
\hline Leersia hexandra & 4,740 & $1,232.40$ & 3.56 & 5,290 & $1,385.45^{2}$ & 4.00 \\
\hline Ludwigia hyssopifolia & 1,980 & 346.90 & 1.00 & 4,290 & $777.35^{7}$ & 2.24 \\
\hline Neptunia oleracea & 1,910 & 394.80 & 1.14 & 2,870 & $607.01^{9}$ & 1.75 \\
\hline Nymphaea lotus & 9,800 & $1,983.50$ & 5.72 & - & - & - \\
\hline Nymphaea odorata & 7,500 & $1,286.30$ & 3.71 & - & - & - \\
\hline Oryza rufipogon & 12,960 & $2,225.20$ & 6.42 & - & - & - \\
\hline Polygonum barbatum & 7,180 & $1,651.40$ & 4.77 & 5,290 & $1,244.74^{3}$ & 3.59 \\
\hline Average & 6,899 & $1,268.51$ & 3.66 & 4,863 & 986.60 & 2.85 \\
\hline
\end{tabular}

Table 5. Fresh weight production (FWP), dry matter production (DMP), and forage carrying capacity (CC) of swamp lowland in wet and dry seasons in Rambutan Village, Banyuasin.

\begin{tabular}{|c|c|c|c|c|c|c|}
\hline \multirow[b]{2}{*}{ Latin name } & \multicolumn{3}{|c|}{ Wet season } & \multicolumn{3}{|c|}{ Dry season } \\
\hline & $\begin{array}{c}\text { FWP } \\
\text { (kg) }\end{array}$ & $\begin{array}{c}\text { DMP } \\
(\mathrm{kg})\end{array}$ & $\begin{array}{c}\text { CC } \\
\left(\text { AU.ha }^{-1} \text {. } \text { yar }^{-1}\right)\end{array}$ & $\begin{array}{c}\text { FWP } \\
(\mathbf{k g})\end{array}$ & $\begin{array}{c}\text { DMP } \\
(\mathrm{kg})\end{array}$ & $\begin{array}{c}\text { CC } \\
\left(\text { AU.ha }{ }^{-1} \cdot \text { year }^{-1}\right)\end{array}$ \\
\hline Cyperus digitatus & 2,590 & 248.90 & 0.72 & 240 & 28.61 & 0.08 \\
\hline Digitaria fuscescens & 790 & 108.00 & 0.31 & 1,100 & 152.79 & 0.44 \\
\hline Eleocharis dulcis & 4,370 & 921.20 & 2.66 & 1,700 & 376.21 & 1.09 \\
\hline Hymenachne acutigluma & 8,540 & $3,139.30$ & 9.06 & 5,900 & $2,181.82$ & 6.29 \\
\hline Hymenachne amplexicaulis & 4,860 & 577.40 & 1.67 & 3,200 & 489.28 & 1.41 \\
\hline Oryza rufipogon & 4,690 & $1,462.80$ & 4.22 & 4,420 & $1,421.03$ & 4.10 \\
\hline Rhynchospora corymbosa & 1,510 & 441.80 & 1.28 & 250 & 77.88 & 0.22 \\
\hline Sesbania exasperata & 1,360 & 111.50 & 0.32 & - & - & - \\
\hline Average & $3,676.67$ & 905.52 & 2.61 & $2,523.75$ & 705.66 & 2.04 \\
\hline
\end{tabular}

\section{Pasture carrying capacity}

The carrying capacity of swamp lowland for Pampangan buffalo pasture in Pulau Layang Village was 3.66 AU.ha- ${ }^{-1}$ year $^{-1}$ during the wet season and 2.85 AU.ha-
${ }^{1}$.year ${ }^{-1}$ in the dry season (Table 4). The carrying capacity of swamp lowland for Pampangan buffalo pasture in Rambutan Village was $2.61 \mathrm{AU}^{-h^{-1}}$.year $^{-1}$ in the wet season and 2.04 AU.ha- ${ }^{-1}$ year $^{-1}$ in the dry season (Table 5). 


\section{Discussion}

Diversity of forage species

There are dominant and palatable forage vegetation species in swamp lowland having potential as buffalo feed, namely Kumpai padi grass (O. rufipogon), Kumpai tembaga ( $H$. acutigluma), and Kumpai minyak $(H$. amplexicaulis), not dominant and palatable such as Kumpai merah (Hymenachne $\mathrm{sp}$ ) and Kemon air ( $N$. oleracea); dominant and non palatable grass species (buffalo doesn't like it) namely Are bolong ( $P$. barbatum). Yet, this grass species would be eaten by the buffaloes if there were no other forage species to be eaten (Table 1). The results of this study are different from the results of research conducted by other people before, the fundamental difference is the existence of differences in internal factors (forage vegetation) and external factors (environment). This research was carried out on swampland while research carried out by others was mostly on dry land or on tidal land. With the difference in place of study, the number, types of forage vegetation that are available will also be different. Besides that, there is also a difference in the production of forages and the carrying capacity of pasture. The renewal of this research is that there is currently no discussion about the analysis of vegetation and the carrying capacity of pasture grazing on swampland.

Ali et al. (2012) conducted a study on swampland vegetation and found 25 species in Pampangan sub-district, while Rohaeni et al. (2005) found 24 species in South Kalimantan, and Camarao and Rodrigues Filho (2001) only found 7 species in Brazil. In Gowa District, there were 15 species found on natural grasslands consisting of 12 species classified as palatable forage (7 kinds of grass and 5 legumes) and 3 non palatable species, all of them are native species (Rinduwati et al. 2016). Based on the number of species encountered (15 species), it can be said that the natural pasture in Gowa District is quite good. Other studies show high diversity of forage species: 33 species in Sota village in Merauke, consisting of $61 \%$ grass, $3 \%$ legume and other plants 36\% (Praptiwi et al. 2017); 22 forage species in Pakistan (Abdullah et al. 2017), 40 forage species consisting of $82-87 \%$ forage grass, $1 \%$ legume and forage consumable by livestock, and $12-17 \%$ those not edible by livestock in West Papua (Yoku et al. 2015). In Tobelo Sub-district, forage pasture consisted of $58.33 \%$ grass, $25 \%$ legume, and $16.67 \%$ other forage (Matulessy and Kastanja 2013; Eoh 2014). Species diversity is influenced by season in which the wet season increases the availability of water needed by plants for growth, especially the grass species, resulting in higher diversity (Kumalasari and Sunardi 2015).

\section{Analysis of forage vegetation}

In Pulau Layang Village, during the wet season, species with the highest Important Value Index (IVI) were Kemon air $(N$. oleracea) having $37.01 \%$ Important Value Index, followed by $32.72 \%$ Are bolong ( $P$. barbatum L) and $27.19 \%$ Eceng gondok (E. crassipes), while the lowest value was Telepuk padi ( $N$. odorata Aiton) and Telepuk gajah (N. lotus) which was $1.84 \%$ each. During the dry season, the highest IVI were Kemon air $(N$. oleracea $)$ with
$39.04 \%$, followed by Are bolong (P. barbatum L) $30.61 \%$ and Kumpai merah (Hymenachne sp.) $20.05 \%$, while the lowest value was Kumpai padi (O. rufipogon) with $13.71 \%$ (Table 2).

In Rambutan Village, during the wet season, species with the highest Important Value Index (IVI) were Purun tikus (E. dulcis) with $71.06 \%$, Kerak maling (D. fuscescens) $42.34 \%$, and Kumpai padi (O. rufipogon) $36.19 \%$. The lowest values were Kumpai tembaga $(H$. acutigluma) and Kumpai minyak (H. amplexicaulis) $1.81 \%$ each. In the dry season, the highest IVI were Purun tikus (E. dulcis) $89.71 \%$, Kumpai padi (O. rufipogon) $54.08 \%$, and Kerak maling (D. fuscescens) $17.71 \%$. The lowest value was Kumpai tembaga (H. acutigluma) $2.33 \%$ (Table 3).

The results also showed that there was a difference in the species richness between the wet and dry seasons. In Pulau Layang Village in the wet season there were 14 forage species and in the dry season, there were only 10 forage species. While Apit-apit (C. cephalotes Vahl) and Kerak maling (D. fuscescens) were not found in the wet season, Purun tikus (E. dulcis), Kumpai padi (O. rufipogon), Tapak darah (C. roseus L. Don), Kangkung merah (I. aquatica Forsk), and Telepuk padi (N. odorata Aiton) were not found in the dry season. In Rambutan Village, in wet season there were 9 forage species, while in the dry season there were only 8 species. In the dry season there was no legume Mutiara ( $S$. exasperate), indicating that this species could not bear the drought and as a result, it would die in the dry season. These results suggest that there are some species that tolerant to water while some others were not. On the other hand, some species are tolerant to drought, while some others are not.

The Important Value Index (IVI) differences among species might be caused by the competition of each species in obtaining soil nutrients and sunlight, as well as climatic factors of the wet and dry seasons as also stated by Parmadi et al. (2016). In addition, there are other influencing factors namely vegetation density. The variation in species diversity and composition indicates that even though a research location has the same age, yet the environmental conditions could result in different vegetation (Syarifuddin 2011). In Pulau Layang Village, species having the highest IVI were Kemon air and Are bolong (37.01 and 32.73\%) while in Rambutan Village were Purun tikus, Kerak maling and Kumpai padi $(71.06 \%, 42.34 \%$, and $36.19 \%)$, indicating that they are the most dominant species among other. A species is considered to be dominant in an area if it has IVI of more than $20 \%$ of all species and co-dominant if the percentage ranges from $10 \%$ to $20 \%$ (Suveltri et al. 2014).

The highest species density of forage vegetation in swamp ecosystem might have resulted from its adaptation and development ability in accordance with environment. This strengthens the study conducted by Oktaviani et al. (2015) that plants with the highest density can adapt to the environment to grow and reproduce under the conditions of low $\mathrm{pH}$ in water and soil. In contrast, plants with the lowest density might be caused by the unsuitable environmental 
factors for the plants to grow and breed, particularly in the acidic water and soil (Samin et al. 2016).

\section{Forage production}

The production of fresh forage at pastures in Pulau Layang Village in the wet season was $6.899 \mathrm{~kg} \mathrm{ha}^{-1}$ year $^{-1}$ and the production of the dry matter was $1,268.51 \mathrm{~kg}$ ha ${ }^{1}$ year $^{-1}$, while in the dry season the production of fresh forage was $4,863 \mathrm{~kg} \mathrm{ha}^{-1}$ year $^{-1}$ and the dry matter production was $986.60 \mathrm{~kg} \mathrm{ha}^{-1}$ year $^{-1}$ (Table 4). This result is higher than those conducted in Canada (Omokanye et al. 2018) and in Timor Tengah Selatan District (Se'u et al. 2015) stating that the average fresh production of pasture in Gowa District in the wet season was $5,350 \mathrm{~kg} \mathrm{ha}^{-1}$ year ${ }^{-1}$ and in the dry season was $1,390 \mathrm{~kg} \mathrm{ha}^{-1}$ year-1 $^{-1}$ (Rinduwati et al. 2016). But the results of this study were lower than the study by Abdullah et al. (2017) in Pakistan who reported that forage production was $8,029.1 \mathrm{~kg} \mathrm{ha}^{-1}$ year $^{-1}$ in the wet season and $5,422.9 \mathrm{~kg} \mathrm{ha}^{-1}$ year $^{-1}$ in the dry season. The forage production of pasture in Sabana Timur Barat on the average ranged from 0.61 to 4.33 tons $\mathrm{ha}^{-1}$ year $^{-1}$ (Manu 2013).

The lowest production usually occurs at the peak of dry season in October and the highest occurs in April (Manu 2013; Damry 2009). The forage production of Pennisetum purpuphoides was 70.4 ton ha $^{-1}$ year $^{-1}$, Setaria sphasielata 44.8 tons ha $^{-1}$ year $^{-1}$, Brachiaria sp 44.7 tons ha $^{-1}$ year $^{-1}$, Pennisetum purpureum 44.6 tons ha $^{-1}$ year $^{-1}$, and Panicum maximum 15,6 tons ha $^{-1}$ year $^{-1}$ (Jarmani and Haryanto 2015). The different amounts of production might have resulted from the differences in vegetation species, types of pasture, and methods used. There are various methods for estimating forage production, but many are inaccurate when applied to certain animal feed plant species. Therefore, it is very important to understand the limitations of technique used to measure forage production (Edvan et al. 2016; Badgery et al. 2017).

In Pulau Layang Village, there were 5 forage species having high fresh production in the wet season, namely Kumpai padi (O. rufipogon) with $12,960 \mathrm{~kg} \mathrm{ha}^{-1}$ year-1, followed by Purun tikus (E. dulcis), Telepuk gajah $(N$. lotus), Are bolong (P. barbatum L) and Telepuk padi $(N$. odorata Aiton), and the lowest one was Kemon air $(N$. olerancia) with $1,910 \mathrm{~kg} \mathrm{ha}^{-1}$ year $^{-1}$. In the dry season the highest fresh production was Kumpai tembaga $(H$. acutigluma) with 7,480 $\mathrm{kg} \mathrm{ha}^{-1}$ year ${ }^{-1}$, followed by Kumpai minyak (H. amplexicaulis), Kumpai merah (Hymenachne sp.), Are bolong ( $P$. barbatum $\mathrm{L})$ and Bento rayap ( $L$. hexandra), and the lowest one was Kemon air $(N$. oleracea) with only $2.870 \mathrm{~kg} \mathrm{ha}^{-1}$ year $^{-1}$. The highest dry matter production in the wet season was Purun tikus $(E$. dulcis) with $2,664.5 \mathrm{~kg} \mathrm{ha}^{-1}$ year $^{-1}$, followed by Kumpai padi (O. rufipogon), Telepuk gajah (N. lotus), Are bolong (P. barbatum L), and Kumpai tembaga (H. acutigluma), and the lowest was Cecengkehan (L. hyssopifolia). In the dry season the highest dry matter production was Kumpai tembaga ( $H$. acutigluma) with $7.480 \mathrm{~kg} \mathrm{ha}^{-1}$ year $^{-1}$, followed by Bento rayap (L. hexandra), Are bolong $(P$. barbatum L), Apit-apit (C. cephalotes Vahl) and Kumpai merah (Hymenachne sp.), and the lowest was Kerak maling (D. fuscescens) with $2,420 \mathrm{~kg} \mathrm{ha}^{-1}$ year $^{-1}$ (Table 4).

In Rambutan Village, the production of fresh forage during the wet season was $3,676.67 \mathrm{~kg} \mathrm{ha}^{-1}$ year $^{-1}$ and the dry matter production was $905.52 \mathrm{~kg} \mathrm{ha}^{-1}$ year $^{-1}$, whereas in the dry season the fresh produce was $2,523.75 \mathrm{~kg} \mathrm{ha}^{-1}$ year $^{-1}$ and the dry matter production was $705.66 \mathrm{~kg} \mathrm{ha}^{-1}$ year $^{-1}$ (Table 5). These results were higher than those of the study conducted by Purwantari et al. (2015) and Praptiwi et al. (2017) who reported that the average availability of forage on palm oil plantation was $1,455.5 \mathrm{~kg} \mathrm{ha}^{-1}$ year $^{-1}$. The forage production during preproduction of rubber

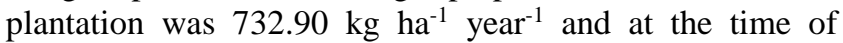
production, it was only $317.83 \mathrm{~kg} \mathrm{ha}^{-1}$ year $^{-1}$ (Pramana et al. 2015).

In Rambutan Village, during the wet season there were 5 forage species having the highest fresh and dry matter production, namely Kumpai tembaga (H. acutigluma) producing $8,540 \mathrm{~kg} \mathrm{ha}^{-1}$ year $^{-1}$ and $3,139.3 \mathrm{~kg} \mathrm{ha}^{-1}$ year $^{-1}$ respectively, followed by Kumpai padi (O. rufipogon), Bento rayap (L. hexandra), Purun tikus (E. dulcis), and Kumpai minyak (H. amplexicaulis), and the lowest one was Kerak maling (D. fuscescens) with $790 \mathrm{~kg} \mathrm{ha}^{-1}$ year $^{-1}$ and $108.0 \mathrm{~kg} \mathrm{ha}^{-1}$ year $^{-1}$, respectively. In the dry season, the highest fresh and dry matter production was Kumpai tembaga ( $H$. acutigluma) of $5,900 \mathrm{~kg} \mathrm{ha}^{-1}$ year $^{-1}$ and $2,181.82 \mathrm{~kg} \mathrm{ha}^{-1}$ year $^{-1}$, followed by Kumpai padi $(O$. rufipogon), Bento rayap (L. hexandra), Kumpai minyak ( $H$. amplexicaulis), and Purun tikus (E. dulcis), and the lowest one was Kasuran (C. digitatus) with $240 \mathrm{~kg} \mathrm{ha}^{-1}$ year $^{-1}$ and $11.92 \mathrm{~kg} \mathrm{ha}^{-1}$ year $^{-1}$, respectively (Table 5). The results of this study were still higher than those conducted by Rostini et al. (2014) stating that the highest fresh forage production of grass Hymenachne amplexicaulis Haes was $1,032 \mathrm{~kg}$ $\mathrm{DM}$ ha $^{-1}$ harvest $^{-1}$ in the high tide season and $518.3 \mathrm{~kg} \mathrm{DM}$ ha $^{-1}$ harvest $^{-1}$ in the low tide season, where the dry matter production ranged from 43.8 to $1.032 \mathrm{~kg} \mathrm{DM} \mathrm{ha}^{-1}$ harvest $^{-1}$ in the high tide season and from 38.5 to $752.8 \mathrm{~kg} \mathrm{DM} \mathrm{ha}^{-1}$ year ${ }^{-1}$ harvest $^{-1}$ in the low tide season.

The higher production of forage in Pampangan Subdistrict compared to that in Rambutan Sub-district might be caused by higher soil fertility of the pasture area in Pampangan. The result of soil analysis showed that the COrganic, N-total, and P-available in Pampangan (Bray I) were higher than those in Rambutan which might be related to the fact that most pasture in Pulau Layang Village (Pampangan) are rice fields which are always given fertilizer. This differs with pasture in Rambutan Village which is only used for grazing without any use of fertilizer. The provision of manure and bioslury fertilizer can increase the production and forage quality of 4.75 tons and 4.36 tons, respectively (Suarna and Budiasa 2016; Jeffery et al. 2018).

\section{Pasture carrying capacity}

In Pulau Layang Village, the carrying capacity for Pampangan buffaloes pasture on the swamp lowland in the wet season was 3.66 $\mathrm{AU}^{-1} \mathrm{year}^{-1}$ and $2.85 \mathrm{AU}^{-1} \mathrm{ye}^{-1}$ during the dry season (Table 4). In Rambutan Village, the carrying capacity for Pampangan buffalo pasture in the wet 
season was 2.61 $\mathrm{AU} \mathrm{ha}^{-1}$ year $^{-1}$ and in the dry season was $2.04 \mathrm{AU} \mathrm{ha}^{-1}$ year $^{-1}$ (Table 5). The results of this study correspond to study conducted by Rostini et al. (2014) which found the carrying capacity of swamp lowland in South Kalimantan was 2.91 AU ha ${ }^{-1}$ year $^{-1}$.

These results were higher than in grassland in South Central Timor District with only 0.24-0.63 AU ha ${ }^{-1}$ year ${ }^{-1}$ (Seu et al. 2015), in natural pastures of Gowa District with $0.88 \mathrm{AU} \mathrm{ha}^{-1}$ year $^{-1}$ (Rinduwati et al. 2016), in pasture in Poso District with 0.63 AU ha ${ }^{-1}$ year $^{-1}$ (Damry 2009; Daru et al. 2014), in Kelei and Didiri villages of Poso Districts with 0.96 and $1.12 \mathrm{AU} \mathrm{ha}^{-1}$ year $^{-1}$ (Karti et al. 2015), However, these results were lower than the study conducted by Muhajirin et al. (2017) stating that the carrying capacity of Padang Mengatas BPTU was 5 AU ha ${ }^{1}$ year $^{-1}$ in the wet season and 3.18 $\mathrm{AU} \mathrm{ha}^{-1}$ year $^{-1}$ in the dry season. Even, Abdullah et al. (2017) reported very high carrying capacity of forage in Pakistan with $24 \mathrm{AU}^{\mathrm{h}} \mathrm{h}^{-1}$ year $^{-1}$ and $16 \mathrm{AU} \mathrm{ha}^{-1}$ year $^{-1}$ in the wet and dry seasons, respectively.

There is a decrease in dry material produced during the dry season because the water condition in swamp lowland is reduced. Decrease in swamp water level resulted in the decrease of photosynthesis which affects the production of the dry matter. Water is the main ingredient needed in photosynthesis. The disruption of metabolic processes in plants will affect plant production. Plant dry weight depicts the accumulation of organic compounds that are successfully synthesized by the plants from inorganic compounds, especially water and $\mathrm{CO}_{2}$ (Lakitan 1995). Water shortages will have a negative effect on plant growth resulting in decreased production (Jun-Feng et al. 2010; Taiz and Zeiger 2002).

The high carrying capacity is related to the high forage production, forage management and selection of good species. Management and strategy to increase forage production require innovative facilitation and training to stockbreeders and farmers to increase their knowledge. These efforts should be supported by government and private companies develop programs regarding the importance of forage in increasing ruminant livestock production (Nigus 2017; Omokanye et al. 2018).

In Pulau Layang Village, in a pasture condition assumed to have one forage species, the highest carrying capacity in the wet season was Purun tikus (E. dulcis) with 7.69 AU ha ${ }^{-1}$ year $^{-1}$, followed by Kumpai padi $(O$. rufipogon) with $6.42 \mathrm{AU} \mathrm{ha}^{-1} \mathrm{year}^{-1}$, Telepuk gajah ( $N$. lotus) with $5.72 \mathrm{AU}^{-1}$ year $^{-1}$, Are bolong (P. barbatum L) with $4.77 \mathrm{AU}^{-1} \mathrm{year}^{-1}$ and Kumpai tembaga $(H$. acutigluma) with $3.90 \mathrm{AU} \mathrm{ha}^{-1}$ year $^{-1}$, respectively, and the lowest was Cecengkehan (L. hyssopifolia) with $1.00 \mathrm{AU}$ $\mathrm{ha}^{-1}$ year $^{-1}$. In the dry season, the highest carrying capacity was Kumpai tembaga (H. acutigluma) with $4.71 \mathrm{AU}^{-1}$ year $^{-1}$, followed by Bento rayap ( $L$. hexandra) with 4.00 AU ha ${ }^{-1}$ year $^{-1}$, Are bolong (P. barbatum L) with 3.59 AU ha $^{-1}$ year $^{-1}$, Apit-apit (C. cephalotes Vahl) with 3.30 AU ha${ }^{1}$ year $^{-1}$ and Kumpai merah (Hymenachne sp.) with $2.82 \mathrm{AU}$ ha $^{-1}$ year $^{-1}$, whereas the lowest was Kerak maling ( $D$. fuscescens) with 1.55 $\mathrm{AU} \mathrm{ha}^{-1}$ year $^{-1}$ (Table 4).
In Rambutan Village, assuming that the pasture had one forage species, the highest carrying capacity in the wet season was Kumpai tembaga (H. acutigluma) with $9.06 \mathrm{AU}$ ha $^{-1}$ year $^{-1}$, followed by Kumpai padi (O. rufipogon) with 4.22 $\mathrm{AU}^{-1} \mathrm{ha}^{-1} \mathrm{year}^{-1}$, Bento rayap (L. hexandra) with 3.29 $\mathrm{AU}$ ha $^{-1}$ year $^{-1}$, Purun tikus (E. dulcis) 2.66 with AU ha ${ }^{-1}$ year $^{-1}$, and Kumpai minyak (H. amplexicaulis) with 1.67 AU ha ${ }^{-1}$ year $^{-1}$, while the lowest was Kerak maling ( $D$. fuscescens) with $0.31 \mathrm{AU} \mathrm{ha}^{-1}$ year $^{-1}$. During the dry season the highest carrying capacity was Kumpai tembaga $(H$. acutigluma) with $6.29 \mathrm{AU} \mathrm{ha}^{-1}$ year $^{-1}$, followed by Kumpai padi (O. rufipogon) with 4.10 $\mathrm{AU}^{-1} \mathrm{ha}^{-1}$ year $^{-1}$, Bento rayap (L. hexandra) with $2.65 \mathrm{AU}^{-1} \mathrm{ya}^{-1} \mathrm{year}^{-1}$, Kumpai minyak (H. amplexicaulis) with $1.41 \mathrm{AU}^{-1} \mathrm{year}^{-1}$, and Purun tikus (E. dulcis) with 1.09 $\mathrm{AU}^{-1}$ year $^{-1}$, while the lowest was Kasuran (C. digitatus) with $0.08 \mathrm{AU} \mathrm{ha}^{-1}$ year $^{-1}$ (Table $5)$. These results indicate that the carrying capacity is very influential with the type of feed plan. In addition, another important thing is cattle grazing system in which livestock grazing must be regulated to avoid over-grazing as the amount of grazing livestock depends on the carrying capacity of the pasture (Salendu and Elly 2014; Cheng et al. 2017; Hashemi 2017).

The results of this study indicated that forage availability is still sufficient to meet feed requirements for Pampangan buffaloes. The population of Pampangan buffaloes in Pulau Layang Village was 487 buffaloes with a grazing area of 500 ha and average carrying capacity of 3.14 AU ha year $^{-1}$. While the number of Pampangan buffaloes of Rambutan Village was 1.735 buffaloes with a pasture area of 1,203 ha and average carrying capacity of 2.45 AU ha-1 year $^{-1}$. It is estimated that there still can be added buffalo cattle as much as $0.31 \mathrm{AU} \mathrm{ha}^{-1}$ year $^{-1}$ in Pulau Layang Village so 155 buffaloes and $0.59 \mathrm{AU}^{\mathrm{h}} \mathrm{ha}^{-1}$ year $^{-1}$ in Rambutan Village 709 buffaloes

In conclusion, there were 19 forage species to have the potential as feeding source of Pampangan buffaloes in South Sumatra. The importance of species indicated by IVI is strongly influenced by grazing locations and seasons. The most important species were Kemon air ( $N$. oleracea) and Are bolong ( $P$. barbatum L) in Pulau Layang Village and Purun tikus (E. dulcis), Kerak maling (D. fuscescens), and Kumpai padi (O. rufipogon) in Rambutan Village. In Pulau Layang Village, the fresh forage and dry matter production in the wet season were 6.90 and 1.27 tons $^{-1}$ year $^{-1}$, while in Rambutan Village they were 3.68 tons ha ${ }^{-1}$ year ${ }^{-1}$ and 0.91 ton $\mathrm{ha}^{-1}$ year $^{-1}$, respectively. The fresh forage production and dry matter production in the dry season in Pulau Layang Village were 4.86 and 0.99 tons ha ${ }^{1}$ year $^{-1}$, while in Rambutan Village were 2.52 tons ha $^{-1}$ year $^{-1}$ and 0.71 tons ha $^{-1}$ year $^{-1}$, respectively. On the average the carrying capacity of the swamp lowland pasture in South Sumatra was 2.79 AU.ha $^{-1}$.year ${ }^{-1}$. As such, forage availability is still sufficient to meet the need for animal feed, and it is estimated the areas can be added buffalo cattle of $0.31 \mathrm{AU} \mathrm{ha}^{-1}$ year $^{-1}$ in Pulau Layang Village and $0.59 \mathrm{AU} \mathrm{ha}^{-1}$ year $^{-1}$ in Rambutan Village. 


\section{ACKNOWLEDGEMENTS}

The authors express their deepest gratitude to the Rector of Sriwijaya University, Palembang, Indonesia through the Chair of the Institute for Research and Community Services by funding this research with the Competitive Leading Research Contract of Sriwijaya University No. 988/UN9.3.1/PP/2017, dated 21 July 2017.

\section{REFERENCES}

Abdullah, M., Rafay, M., Sial, N., F. Rasheed, F., Nawaz M.F., Nouman, W., Ahmad, I., Ruby, T and Khalil, S. 2017. Determination of forage productivity, carrying capacity and palatability of browse vegetation in arid rangelands of Cholistan Desert (Pakistan). Appl Ecol Environ Res 15 (4): 623-637.

Ali AIM, Sandi S, Muhakka, Riswandi. 2012. The quality of forage feed of the swampy lowland of Pampangan buffalo pasture. Prosiding InSINAS 2012. 307-312.

Badgery WB, Millar GD, Broadfoot K, Michalk DL, Cranney P, Mitchell D, Van de Ven R. 2017. Increased production and cover in a variable native pasture following intensive grazing management. Anim Prod Sci 57: 1812-1823.

BPS [Central Statistics Agency]. 2010. Swamp lowland Area of Indonesia. Directorate General of Food, Ministry of Agriculture and Central Statistics Agency Jakarta.

BPS [Central Statistics Agency]. 2014. South Sumatra in Figure 2015. Central Statistics Agency of South Sumatra Province, Palembang.

Camarao AP, Rodrigues Filho JA. 2001. Botanical composition of the available forage and the diet of water buffalo grazing native pastures of the medium Amazon region, Brazil. Buffalo J 3: 307-316.

Center for Agricultural Technology Assessment in South Sumatra. 2011 Pampangan buffalo as South Sumatra's Nutfah plasm. Center for Agricultural Technology Assessment in South Sumatra, Palembang.

Cheng D, Peili S, Xianzhou Z, Ning Z, Xi C, Shoubao G, Wanrui Z. 2017. The rangeland livestock carrying capacity and stocking rate in the Kailash Sacred Landscape in China. J Resour Ecol 8 (6): 551-558.

Damry. 2009. Production and content of forage nutrition of natural pasture of North Lore Subdistrict of Poso District. Jurnal Agroland 16 (4) 296-300. [Indonesian]

Daru TP, Suhardi, Yusuf R., Wibowo A, Pujowati P. 2012. Carrying capacity of feed forage on the ruminants development in West Kutai District. Jurnal Teknologi Pertanian 8 (1): 30-36. [Indonesian]

Daru TP, Yulianti A, Widodo E. 2014. Forage potential of palmoil plantation as beef cattle feed in Kutai Kartanegara District. Media Sains 7: 79-86. [Indonesian]

Delima M, Karim A, Yunus M. 2015. Study of feed forage production potency on existing areas potential to increase ruminant livestock population in Aceh Besar District. Jurnal Agripet 15 (1): 33-40. [Indonesian]

Dwyanto K, Handiwirawan E. 2006. Strategy of buffalo cattle development: network and distribution aspects. Pros. Nationa Workshop of Buffalo Cattle Business to Support the Beef Adequacy Program. Sumbawa, 4-5 August 2006. Center for Animal Husbandry Research and Development in cooperation with the Directorate of Nursery, Director General of Animal Husbandry of West Nusa Tenggara Province, Mataram. [Indonesian]

Edvan RL, Bezerra LR, Marques CAT, Carneiro MSS, Oliveira RL, Ferreira RR. 2016. Methods for estimating forage mass in pastures in a tropical climate. Revista de Ciências Agrárias 39 (1): 36-45.

Eoh M. 2014. Carrying capacity and composition of feed substance of buffalo pasture of Pulau Moa. Agrinimal 4 (2): 77-82.

Hashemi N. 2017. Recognizing the potential of sustainable use of pasture resources in South Khorasan Province with approach of carrying capacity. Environ Ecosyst Sci 1 (2): 9-12.

Jarmani SN, Haryanto B. 2015. Improving productivity of animal feed forage to support buffalo pasture capacity of Kampar District of Riau (A suggestion of thought). Jurnal Pastura 4 (2): 95-99. [Indonesian]

Jefferya RP, Simpsona RJ, Lambersc H, Orcharda S, Kidda DR, Halingb RE, Ryana MH. 2018. Contrasting communities of arbuscularforming root symbionts change external critical phosphorus requirements of some annual pasture legumes. Appl Soil Ecol. DOI: 10.1016/j.apsoil.

Jung-Feng S, Guo MX, Lian, JR, Xiaobin P, Guo WY, Ping CX. 2010. Gene expression profile of response to water stress at the jointing stage in wheat. Agric Sci China 9 (3): 323-330.

Karti PDMH, Abdullah L, Prihantoro I. 2015. Exploration and productivity of pastures of East Pamona Subdistrict of Poso District of Mid Sulawesi. Jurnal Pastura 4 (2): 91-94. [Indonesian]

Kleden MM., Ratu MRD, Randu MDS. 2015. Feed forage carrying capacity in coffee plantation areas and natural pasture of East Flores District of East Nusa Tenggara. Jurnal Zootek 35 (2): 340-350. [Indonesian]

Kumalasari NR, Sunardi. 2015. Variety of feed forage potential vegetation in rice field areas of different height conditions. Jurnal Pastura 4 (2): 59-61. [Indonesian]

Lakitan B. 1995. Plant Physiology and Plant Development. Raja Grafindo Persada, Jakarta. [Indonesian]

Manu AE. 2013. Productivity of sabana pasture of West Timor. Jurnal Pastura 3 (1): 25-29.

Muhajirin, Despal, Khalil. 2017. Pemenuhan kebutuhan nutrien sapi potong bibit yang digembalakan Fulfilling the nutrient needs of grazed nursery beef cattle of Padang Mengatas. Buletin Makanan Ternak 104 (1): 9-20. [Indonesian]

Muhakka, Riswandi, Ali AIM. 2013. Morphological and reproductive characteristics of Pampangan Buffaloes of South Sumatra Province. Jurnal Sain Peternakan Indonesia 8 (8): 89-106. [Indonesian]

Mulyani A, Sarwani M. 2013. Characteristics and potential of sub-optimal land for agricultural development. Jurnal Sumberdaya Lahan 7 (1): 47-55. [Indonesian]

Oktaviani SI, Santri DJ, Dayat E. 2015. Diversity of swamp vegetation of Tanjung Lago Subdistrict. Jurnal Lahan Suboptimal 4 (2): 133-148. [Indonesian]

Omokanye A, Yoder C, Sreekumar L, Vihvelin L, Benoit M. 2018. Forage production and Economic performance of pasture rejuvenation methods in Northern Alberta, Canada. Suit Agric Res 7 (2): 94-110.

Parmadi JC EH, Dewiyanti I, Karina S. 2016. Important value index of mangrove vegetation in Kuala Idi area, East Aceh District. Jurnal Ilmiah Mahasiswa Kelautan dan Perikanan Unsyiah 1 (1): 82-95.

Praptiwi II, Susanti DS, Damayanti AT, Mangera Y. 2017. The potential of various vegetation species as animal feed forage in the pasture of Sota Village of Merauke District. Agricola 7 (1): 15-24. [Indonesian]

Purnomo J. 2006. Animal Feed Forage in Indonesia. Jakarta. [Indonesian]Agricultural Research and Development Agency of the Ministry of Agriculture

Purwantari ND, Tiesnamurti B, Adinata Y. 2015. Availability of forage sources in palm oil plantations for cattle grazing. Watazoa 25 (1): $47-$ 54

Rinduwati., Hasan S, Syamsu JA, Useng D. 2016. Carrying capacity and botanical diversity of pastoral range in Gowa Regency. Intl $\mathbf{J}$ Sci: Basic Appl Res 29 (3) : 105-111.

Rohaeni ES, Darmawan A, Qomariah R, Hamdan A, Subhan A. 2005. Inventory and characterization of swamp buffaloes as germplasm. [Research Report]. Center for Agricultural Technology Assessment in South Kalimantan, Banjarbaru. [Indonesian]

Rostini T, Abdullah L, Wiryawan KG, Karti PDMH. 2014. Production and nutrition potency of swamp local forage in South Kalimantan as ruminant feed. Glob J Anim Sci Livestock Prod Anim Breed 2 (2): 107-113.

Salendu AHS, Elly FH. 2014. Potential development of forage for cattle under the coconut trees in Lolayan Subdistrict of Bolaang Mongondow District. Jurnal Pastura 4 (1): 7-10. [Indonesian]

Samin AN, Chairul, Mukhtar E. 2016. Analysis of coastal vegetation in tourist area of Pasir Jambak, Kota Padang. Jurnal Biocelebes 10 (2): 32-42. [Indonesian]

Se'u VE, Kartib PDMH, Abdullah L. 2015. Botanical composition, grass production, and carrying capacity of pasture in Timor Tengah Selatan District. Media Peternakan 38 (3):176-182. [Indonesian]

South Sumatra Province Animal Husbandry Office. 2014. South Sumatra Animal Husbandry Statistics in 2014. South Sumatra Province Animal Husbandry Office, Palembang.

Suarna IW, Budiasa IKM. 2016. Effect of organic fertilizers on the production and quality of mixed pasture on the dry land of Sebudi Karangase Village. Majalah Ilmiah Peternakan 19 (3): 125-128. 
Sutaryo D. 2009. Calculation of Biomass. An Introduction to the Study of Carbon and Carbon Trading. Wetlands International Indonesia Programme, Bogor.

Suveltri B, Syam Z, Solfiyeni. 2014. Analysis of weed vegetation in plantations of maize (Zea mays L.) on maximum tillage in District of Lima Puluh Kota. Jurnal Biologi Universitas Andalas (J Bio UA) 3 (2): 103-108. [Indonesian]

Syarifuddin H. 2011. Composition and Structure of animal feed forage under the trees of palm oil plantation. Agrinak 1 (1): 25-30.

Taiz L, Zeiger E. 2002. Plant Physiology. 3 rd ed. Sinauer, New York.
Thalib C, Herawati T, Hastono. 2014. Strategy of increasing buffalo productivity through the improvement of feed and genetics. Wartazoa 24 (2): 83-96.

Yasin S. 2013. Eating behavior of ruminants as phenology bioindicators and dynamics of pasture. Jurnal Pastura 3 (1) : 1-4. [Indonesian]

Yoku O, Supriyantono A, Widayati T, Sumpe I. 2014. Production of natural pasture and potency of Balinese cow development in supporting the meat adequacy program in West Papua. Jurnal Pastura 3 (2): 102-105. [Indonesian]

Yoku O, Supriyantono A, Widayati T, Sumpe I. 2015. Composition of botany and distribution of local forage species of natural pasture in West Papua. Jurnal Pastura 4 (2): 62-65. [Indonesian] 